\title{
Restaurant consumer satisfaction research as a basis for ensuring rational consumption patterns
}

\author{
Tatyana Solosichenko, Nadezhda Goncharova*, and Natalia Merzlyakova \\ Ural State University of Economics, Russian Federation
}

\begin{abstract}
The article is devoted to the study of the degree of satisfaction of consumers of a public catering enterprise as the basis for ensuring rational consumption patterns at the present stage of economic sustainability development and the most important criterion of the company's performance in order to obtain long-term profit. Customer satisfaction research is one of the main directions in marketing. The provision of rational consumption patterns, according to the authors, in line with the assessment of consumer satisfaction is influenced by many factors such as the environment, consumer behavior patterns, the quality of food and service, the atmosphere, and the company's image. The main methods we use in assessing satisfaction are SERVQUAL, NPS, and CSI. The CSI index assesses the level of customer satisfaction immediately after interacting with the company. It is based on identifying product properties that are important to the consumer. NPS is one of the best tools for determining the effectiveness of a company in determining the degree of customer loyalty. The concept of "SERVQUAL" reflects in detail the peculiarities of customer perception of service services, allows them to come to an understanding of the standard that will be most in demand among customers.To describe the "Customer Satisfaction" process, the authors used a process passport, which contains the following elements: process name, process definition, process goal, process inputs / outputs, process consumers, process resources, process performance indicators and their criteria, methods of measuring indicators.From the analysis of CSI data obtained from clients, conclusions are drawn about the most important indicators. In this case, it is the quality of the food, the atmosphere, the level of service. Based on the study, recommendations have been developed aimed at increasing the degree of consumer satisfaction and increasing the competitiveness of the catering enterprise.
\end{abstract}

\section{Introduction}

Resource saving and ensuring rational consumption patterns in modern conditions worries the entire world community. The economic model of modern society is based on the identification of socio-economic development with the continuous growth of consumption,

\footnotetext{
${ }^{*}$ Corresponding author: nadin1325x@yandex.ru
} 
and hence the production of material goods. This is mainly due to the use of difficult renewable natural resources. Such a model is not only insufficiently conducive to progress, but also creates new global problems. Consumers can play an important role in changing this consumption pattern.

Customer satisfaction is one of the important criteria for the efficiency of the company in order to rationalize the use of resources, and the emergence of effective consumption patterns, and with this taking into account the receipt of long-term profits. Many researchers argue that customer satisfaction is the key to the success of every company; it is a strategically important advantage over competitors.

To date, it has been proven that consumers with low satisfaction switch faster to similar products or services. Attracting a new consumer is much more difficult than retaining an existing one, so it is important for companies to form the right attitude to their product, because the consumer is guided by the expectations from the offer. Consequently, organizations should provide in advertising only real qualities of a product or service, thereby forming the desired expectation from the product.

Consumer satisfaction research is one of the main directions in marketing [1-10]. The main attention of scientists was paid in the early nineties, a whole galaxy of scientists, such as Woodruff and Guardiala, Vana and Qualls, Parashuraman, Zeitham and Berry, George and Jones, and others, were engaged in such research and development of appropriate methods.

It is believed that the assessment of customer satisfaction is influenced by many factors, the environment affects consumer behavior and quality assessment, the atmosphere, which affects the image of the restaurant and, in general, the attitude towards it. To create shortterm pleasure, catering companies have to work hard to ensure high quality service, reasonable pricing, and a developed assortment. Only with the help of marketing research the current situation can be identified, the degree of customer satisfaction can be determined, and a competent management decision can be made on the basis of this data.

\section{Research materials and methods}

The purpose of our study is to present the methodological and practical aspects of technologies in assessment of the degree of consumer satisfaction with the services of public catering enterprises. The research methodological base is based on the use of such methods as SERVQUAL, NPS, CSI.

To make management decisions and choose a company's strategy, it is necessary to conduct a study of the degree of customer satisfaction. In addition to determining the level of customer satisfaction, the research results help to determine the strengths and weaknesses of the enterprise, as well as the factors affecting them [11].

In Russia a system for measuring customer satisfaction has not been developed yet, which will allow not only to measure the degree of satisfaction, but also to form the necessary algorithm. There are some features of the Russian market that do not allow the use of Western methods, due to the specifics of the conditions, therefore, it is necessary to highlight the main criteria for the methodology for researching customer satisfaction.

The customer satisfaction survey methodology should contain the following aspects:

- cost-effective systematic research;

- easy-to-understand polls that do not cause negative reactions;

- comparative analysis between the directions of the organization.

Using these parameters, we carried out a comparative analysis of the three main methods of researching customer satisfaction. Which includes three methods: the Customer Satisfaction Index (CSI), developed in 1989 by the Stockholm School of Economics, the Net Promoter Score (NPS), created in 2003 by F. Reicheld, and the SERQUAL ". 
The degree of satisfaction is expressed in terms of the index, which makes it possible to assess the transformation of indicators over time. It also helps you compare the performance of competing organizations.

Table 1. Methods for assessing customer satisfaction

\begin{tabular}{|l|l|}
\hline Method & \multicolumn{1}{c|}{ Description } \\
\hline $\begin{array}{l}\text { CSI } \\
\text { (Customer } \\
\text { Intisfaction }\end{array}$ & $\begin{array}{l}\text { The index assesses the level of customer satisfaction immediately after interacting } \\
\text { with a company. The main idea is that customer satisfaction depends on not only } \\
\text { the properties of the product / service, but also on how important these properties } \\
\text { are for the consumer. CSI is a versatile tool that can be used in both the B2C } \\
\text { market and B2B. }\end{array}$ \\
\hline $\begin{array}{l}\text { NPS (Net } \\
\text { Promoter }\end{array}$ & $\begin{array}{l}\text { The index assesses the degree of customer commitment and loyalty, and assesses } \\
\text { the willingness to recommend a company to friends based on their customer } \\
\text { experience. NPS is one of the best tools for measuring the performance of a } \\
\text { company. The calculation of the index determines the proportion of loyal and } \\
\text { disloyal customers, to determine the properties that to a greater extent reveal the } \\
\text { general degree of loyalty. NPS is a versatile tool that can be used in both B2C and } \\
\text { B2B markets. }\end{array}$ \\
\hline SERQUAL & $\begin{array}{l}\text { The concept of "SERVQUAL" reflects in detail the peculiarities of customer } \\
\text { perception of service services, allows them to come to an understanding of such a } \\
\text { standard that will suit customers. }\end{array}$ \\
\hline
\end{tabular}

CSI, NPS and SERQUAL can be more effectively used together to better reflect customer satisfaction and build long-term loyalty. The peculiarities of the SERQUAL method are that it is ideal for researching restaurant services. A comparison of two competing customer satisfaction methodologies (NPS and CSI) is presented in Table 2.

Table 2. Comparison of customer satisfaction techniques (NPS and CSI)

\begin{tabular}{|c|c|c|}
\hline Parameters & NPS & CSI \\
\hline Types of questions & Open and closed & Closed questions \\
\hline Specificity & $\begin{array}{l}\text { The respondent himself } \\
\text { names the assessment } \\
\text { factors }\end{array}$ & $\begin{array}{l}\text { The respondent is offered specific factors to } \\
\text { evaluate }\end{array}$ \\
\hline Respondent's answer & Deployed & Limited, rarely deployed \\
\hline Rating system & $\begin{array}{l}11 \text { - point scale (from } 0 \text { to } \\
10 \text { ) }\end{array}$ & 11 - point scale (from 0 to 10 ) \\
\hline $\begin{array}{l}\text { Method of carrying } \\
\text { out }\end{array}$ & $\begin{array}{l}\text { Personal Interaction } \\
\text { Online (Google Form) }\end{array}$ & Personal Interaction / Online \\
\hline Time & 5-10 minutes & 5-10 minutes \\
\hline $\begin{array}{l}\text { Satisfaction indicators } \\
\text { calculation }\end{array}$ & $\begin{array}{l}\text { Simple calculations based } \\
\text { on difference of shares }\end{array}$ & $\begin{array}{l}\text { More complex calculations. Calculation of } \\
\text { a large number of indicators. }\end{array}$ \\
\hline $\begin{array}{l}\text { Loyalty indicator } \\
\text { calculation }\end{array}$ & - & Based on a separate block of questions \\
\hline Quality control & $\begin{array}{l}\text { Produced by establishing } \\
\text { responsibility for quality }\end{array}$ & $\begin{array}{l}\text { The questionnaire can include a block of } \\
\text { questions about the work of specific } \\
\text { departments }\end{array}$ \\
\hline
\end{tabular}

The NPS technique has the advantage of being simpler to understand, but nevertheless effective. It best meets the criteria developed. This method allows you to consolidate the understanding that systematization and regular study of consumer preferences are needed. Ideally, the NPS index can be supplemented with additional elements and a hybrid of the method can be created. In this case, the technique will be able to perform new functions, taking the best from other techniques. Therefore, it should be noted that the NPS 
methodology is the basis for developing a new approach to measuring customer satisfaction.

\section{Results and discussion}

To describe the Customer Satisfaction process, we used a process passport, which contains the following elements: process name, process definition, process goal, process inputs / outputs, process consumers, process resources, process performance indicators and their criteria, methods of measuring indicators. We used the technologies of the listed methods on the example of an oriental restaurant. The average check is 800-1000 rubles. The restaurant also provides a wide range of additional services, such as a children's room, food delivery, offsite events, as well as banquets, adult and children's master classes. Waiters, chefs, managers and bartenders are regularly certified.

The developed process passport is presented in Table 3.

Table 3. Passport of the "Customer Satisfaction" process based on the "SERVQUAL" methods

\begin{tabular}{|l|l|}
\hline \multicolumn{1}{|c|}{ Name } & \multicolumn{1}{|c|}{ Customer satisfaction assessment based on SERVQUAL methods } \\
\hline $\begin{array}{l}\text { Purpose of the } \\
\text { process }\end{array}$ & $\begin{array}{l}\text { Analysis and improvement of processes and quality management } \\
\text { systems }\end{array}$ \\
\hline Process inputs & Reviews, letters from visitors with suggestions, wishes \\
\hline Process consumers & $\begin{array}{l}\text { Visitors } \\
\text { Top management } \\
\text { Workers }\end{array}$ \\
\hline Process outputs & $\begin{array}{l}\text { Reports on the results of the questionnaire } \\
\text { Improvement action plan Updating the quality policy and quality } \\
\text { objectives }\end{array}$ \\
\hline Resources & $\begin{array}{l}\text { Workers } \\
\text { Infrastructure } \\
\text { Environment for the functioning of the process (moral and } \\
\text { psychological climate, physical and mechanical parameters of the } \\
\text { environment according to SanPiN). }\end{array}$ \\
\hline Process indicators & $\begin{array}{l}\text { Customer Satisfaction Ratio } \\
\text { Satisfaction change rate consumers }\end{array}$ \\
\hline $\begin{array}{l}\text { Process performance } \\
\text { criteria }\end{array}$ & $\begin{array}{l}\text { Coefficient of satisfaction of external consumers Ky not less than 75\% } \\
\text { Coefficient of change in customer satisfaction Kmeas not more than 3\% }\end{array}$ \\
\hline $\begin{array}{l}\text { Methods for } \\
\text { measuring indicators }\end{array}$ & Analysis, comparison, statistical methods \\
\hline
\end{tabular}

The number of interviewed visitors to the company was 120 people. The survey was conducted using the online method.

The survey results are presented in Table 4.

Table 4. Results of the survey using the "SERVQUAL»

\begin{tabular}{|l|l|l|l|l|l|}
\hline \multicolumn{1}{|c|}{ Criterion } & \multicolumn{5}{|c|}{ Quality factors assessed } \\
\hline $\begin{array}{l}\text { Tangibilit } \\
\text { (material } \\
\text { elements) }\end{array}$ & $\begin{array}{l}\text { Availability of } \\
\text { modern trade } \\
\text { equipment in } \\
\text { the restaurant }\end{array}$ & Restaurant interior & $\begin{array}{l}\text { The appearance } \\
\text { of the } \\
\text { employees of } \\
\text { the "contact } \\
\text { zone" }\end{array}$ & $\begin{array}{l}\text { Availability } \\
\text { of } \\
\text { advertising } \\
\text { materials, } \\
\text { table tents }\end{array}$ & Total \\
\hline $\begin{array}{l}\text { Average } \\
\text { score }\end{array}$ & 4 & 4 & 4 & 5 & 4,25
\end{tabular}


Table 4. Continued

\begin{tabular}{|c|c|c|c|c|c|}
\hline Reliability & $\begin{array}{lr}\text { Fulfillment } & \text { of } \\
\text { obligations } & \text { to } \\
\text { provide } & \text { the } \\
\text { declared } & \\
\text { services } & \\
\end{array}$ & $\begin{array}{l}\text { Accuracy } \\
\text { performance of } \\
\text { declared services }\end{array}$ & $\begin{array}{l}\text { The } \\
\text { resolvability of } \\
\text { the client's } \\
\text { problem } \\
\text { situations }\end{array}$ & $\begin{array}{l}\text { Trustworthy } \\
\text { reputation }\end{array}$ & $\begin{array}{l}\text { No errors and } \\
\text { inaccuracies } \\
\text { in service }\end{array}$ \\
\hline $\begin{array}{l}\text { Average } \\
\text { score }\end{array}$ & 4 & 5 & 4 & 3 & $3 / 3,8$ \\
\hline $\begin{array}{l}\text { Personnel } \\
\text { reactivity }\end{array}$ & $\begin{array}{l}\text { Discipline } \\
\text { employees }\end{array}$ & $\begin{array}{l}\text { Efficiency in the } \\
\text { provision of services }\end{array}$ & $\begin{array}{l}\text { Striving to help } \\
\text { solve client } \\
\text { problems }\end{array}$ & $\begin{array}{l}\text { Quick } \\
\text { response }\end{array}$ & Total \\
\hline $\begin{array}{l}\text { Average } \\
\text { score }\end{array}$ & 4 & 5 & 5 & 4 & 4 \\
\hline $\begin{array}{l}\text { Competen } \\
\text { ce of } \\
\text { staff }\end{array}$ & $\begin{array}{lr}\text { Contact } & \text { zone } \\
\text { employees } & \text { are } \\
\text { able to } & \\
\text { resolve } & \text { a } \\
\text { question } & \\
\end{array}$ & $\begin{array}{ll}\begin{array}{l}\text { Employees } \\
\text { courtesy }\end{array} & \text { show }\end{array}$ & $\begin{array}{l}\text { Employees } \\
\text { provide } \\
\text { effective } \\
\text { customer } \\
\text { service }\end{array}$ & $\begin{array}{l}\text { Employees } \\
\text { competently } \\
\text { advise } \\
\text { clients }\end{array}$ & Total \\
\hline $\begin{array}{l}\text { Average } \\
\text { score }\end{array}$ & 4 & 5 & 5 & 5 & 4,75 \\
\hline Empathy & $\begin{array}{l}\text { Manifesting an } \\
\text { individual } \\
\text { approach to the } \\
\text { client }\end{array}$ & $\begin{array}{l}\text { Employees are focused } \\
\text { on solving the problem } \\
\text { of their customers }\end{array}$ & $\begin{array}{l}\text { Employees } \\
\text { know the needs } \\
\text { of their } \\
\text { customers }\end{array}$ & $\begin{array}{l}\text { Employees } \\
\text { are } \\
\text { personally } \\
\text { involved in } \\
\text { the decision }\end{array}$ & Total \\
\hline $\begin{array}{l}\text { Average } \\
\text { score }\end{array}$ & 5 & 5 & 5 & 5 & 5 \\
\hline
\end{tabular}

Thus, we can conclude that one of the company's strengths is communication with consumers. Empathy played a key role in this. However, the lowest indicator is reliability. It is also related to the loyalty of the visitors.

Survey of customer satisfaction using the NPS method.

In the course of marketing research, 150 people were interviewed

According to the results of the study of the NPS index, the following data were revealed in visitors:

- field of activity;

- restaurant attendance;

- brand perception;

- NPS index;

- advantages of the restaurant.

To identify the target audience of the restaurant, it was decided to research their field of activity.

The main areas of activity of restaurant visitors were identified:

- qualified specialist $16 \%$;

- middle manager $16 \%$;

- top manager $15 \%$;

- entrepreneur $21 \%$;

- service worker $13 \%$.

One of the important elements of this study is restaurant traffic. How often they visit, whether guests return, and how long have they visited.

Thus, the majority of the restaurant's visitors were not for the first time, in terms of frequency of visits - more visit the restaurant 1-3 times a month (40\%), 16\% visit the restaurant several times a week. 
According to the research, more than 4-5 guests visit the restaurant, which means that most of the respondents are regular guests.

The respondents highlighted the following advantages of the restaurant:

- location;

- atmosphere;

- tasty.

From the suggestions of the respondents:

- increase the portions of dishes;

- make a vegetarian menu;

- make the lighting brighter;

- to expand the assortment of pilaf;

- expand the bar list;

- make a convenient parking;

- to organize entertainment events, dance floor.

Thus, the NPS index is $80 \%$, which is higher than the norm, which indicates the satisfaction of visitors.

The next method is based on a survey of consumers who have taken a particular action in relation to a product or service. The survey is carried out online or in person.

The Customer Satisfaction Index (CSI) is a general assessment that consists of assessments of the quality of a product or service, the quality of service, and the quality of the product or service offering. 100 people took part in the survey, of which 54 were women and 46 were men. The age of the survey participants ranged from 18 to 55 years old. A large number of respondents from 25 to 40 years old - 53\% [12]. Usually restaurants in the eastern direction are visited by married people with children $(42 \%)$, in second place, by a small margin, are single people $(30 \%)$. The income of the respondents to a greater extent is $30,000-50,000$ rubles ( $38 \%$ ), from 10,000 to 30,000 rubles are earned by $34 \%$ of the respondents. $28 \%$ earn $50,000-100,000$ rubles.

The parameters were compiled by the author and were identified based on reviews of the restaurant. The survey results are presented in Table 5.

Table 5. CSI Results

\begin{tabular}{|l|l|l|}
\hline Parameter & Parameter & Evaluation \\
\hline Food quality & 10 & 8 \\
\hline Atmosphere & 8 & 10 \\
\hline Range & 7 & 6 \\
\hline Competence of staff & 8 & 9 \\
\hline Employee appearance & 6 & 6 \\
\hline Waiting time for employees & 10 & 7 \\
\hline
\end{tabular}

CSI Customer Satisfaction Index Calculation Results:

Food quality $80 \%$

Atmosphere 80\%

Assortment 42\%

Staff competence $72 \%$

Employee appearance 56\%

Waiting time for employees $70 \%$

Based on the analysis of the data received from clients, we will draw conclusions about the most important indicators. In this case, it is the quality of the food, the atmosphere, the level of service.

With an increase in the CSI index by $1-2 \%$, revenue can increase by $20 \%$.

Based on the conducted research, recommendations have been developed aimed at increasing the degree of customer satisfaction (table 6). 
Table 6. Action program to improve customer satisfaction

\begin{tabular}{|l|l|}
\hline \multicolumn{1}{|c|}{ Actions } & \multicolumn{1}{c|}{ Result } \\
\hline Customer base start (CRM) & $\begin{array}{l}\text { Access to the customer base, data automation, reduction of } \\
\text { mailing costs, customer loyalty }\end{array}$ \\
\hline Loyalty building activities & $\begin{array}{l}\text { Schedule of events for the year, notifying guests, building } \\
\text { loyalty and strengthening the company's image }\end{array}$ \\
\hline $\begin{array}{l}\text { Advertising support for the loyalty } \\
\text { building program }\end{array}$ & $\begin{array}{l}\text { Guests are aware of current promotions, an increase in the } \\
\text { flow of guests }\end{array}$ \\
\hline
\end{tabular}

\section{Conclusion}

Studies showed that a circle of regular guests visiting the institution had been formed. The SERVQUAL methodology made it possible to conclude that one of the company's strengths is communication with consumers. The apathy factor played a key role in this. However, the lowest indicator is reliability. It is also related to the loyalty of the visitors. Using the NPS method, it was revealed that the restaurant is a place "for all occasions" and the norm of the NPS index for the restaurant business is $75 \%$.

A company's high degree of customer satisfaction has several benefits. First, the rational use of resources as a modern consumption model, increasing consumer loyalty, the company's image, respectively, the development of the brand, as well as the price elasticity of demand. One of the main advantages is that consumers are ready to recommend a product or service to friends and acquaintances; this creates a commitment to the company and its sustainable development. It is necessary to understand that it is in the interests of business to find new solutions that allow moving to models of sustainable consumption and production. There is a need to improve understanding of the environmental and social impacts of products and services in terms of both the life cycle of the product itself and how it changes when consumed in different living conditions. Entrepreneurs can also use their innovative potential to develop solutions that can inspire and encourage people to lead more sustainable lives, thereby reducing their environmental impact and increasing their wellbeing.

\section{References}

1. G.F. Balakina, M.P. Kulikova, Coal, 12, 32 (2019)

2. N.B. Iacovo, L.M. Kapustin, Manager, 9, 74 (2018)

3. D.A. Karh, M.P. Morozova, Manager, 9, 56 (2018)

4. F. Ssennoga, G. Mugurusi, P. N. Oluka, SA, 3 (2019)

5. J. DeBacker, B. T. Heim, A. Tran, JFEV, 1, 122 (2015)

6. K. Yousefi, M. Vesal, H. Pilvar, QREF (2019)

7. M. Klein, L. Linnemann, EER, 120 (2019)

8. N. A. Goncharova, T. Zh. Solosichenko, N. V. Merzlyakova, IJSCM, 8, 815 (2019)

9. N. Pisani, A. Kourula, A. Kolk, R. Meijer, JWB, 52, 591 (2017)

10. E. K. Kemsley, M. Defernez, F. Marini, FC, 105, 102 (2019)

11. J. Swaffield, D. Evans, D. Welch, Geoforum, 89, 43 (2018)

12. T. E. Baer, E. A. Scherer, E. W. Fleegler, A. Hassan, JAH, 57, 601 (2015) 